\title{
VENACULAR POETS IN BEDE AND MUIRCHÚ A COMPARATIVE STUDY OF EARLY INSULAR CULTURAL HISTORIES
}

\author{
BY COLIN A. IRELAND
}

This comparative study examines the treatment of named vernacular poets from the Gaelic and Anglo-Saxon worlds in the subsequent literary cultural histories of their traditions. Both societies developed sophisticated bilingual intellectual cultures. After a brief survey of historical poets and anonymous secular texts from both vernacular literatures, this essay examines two accounts that involve vernacular poets from Latin texts written by clerics. Muirchú maccu Machtheni wrote Vita Sancti Patricii (ca. 690) and briefly mentioned the presence of the poets Dubthach maccu Lugair and Fiacc Finn Sléibte at the pagan court of Lóegaire mac Néill in Tara in the fifth century. Bede devoted a full chapter of his Historia Ecclesiastica Gentis Anglorum (ca. 731) to the poet Cadmon at the monastery of Whitby sometime in the second half of the seventh century. The presence of these three vernacular poets in the works of two clerics suggests their perceived potential contributions to the Church. But their treatment in later cultural history differs markedly between the self-referential Gaelic world and more reticent Anglo-Saxons. In the Gaelic tradition Dubthach and Fiacc are recorded in law tracts, hagiography, martyrologies, genealogies, prose narratives, and poems. In the Anglo-Saxon tradition Codmon does not exist outside of Bede's account. It is suggested that the legally recognized social rank, formal training, and professional status of poets in Gaelic society helps explain the discrepancy in subsequent cultural acknowledgement.

Early Gaelic and Old English vernacular literatures are the earliest in Western Europe outside of the Mediterranean world of Latin and Greek literatures. Both Gaelic and Anglo-Saxon societies developed highly evolved bilingual intellectual cultures in Latin and in their respective vernaculars as a result of their conversions to Christianity. ${ }^{1}$ Their literatures in the vernacular were probably encouraged by

1 Fortunately, good surveys exist for Anglo-Saxon literary culture that show the relationship between Latin and the vernacular. See, for example, Stanley B. Greenfield and Daniel G. Calder, A New Critical History of Old English Literature (New York, 1986) with a survey of the Anglo-Latin background by Michael Lapidge; and Malcolm Godden and Michael Lapidge, eds., The Cambridge Companion to Old English Literature (Cambridge, 1991). Some studies of Gaelic culture that address the issues in the period under discussion include Jane Stevenson, "The Beginnings of Literacy in Ireland," Proceedings of the Royal Irish Academy 89C (1989): 127-65; eadem, "Literacy and Orality in Early Medieval Ireland," in Cultural Identity and Cultural Integration, ed. Doris Edel (Dublin, 1995), 11-22; T. M. Charles-Edwards, "The Context and Uses of Literacy in Early Christian Ireland," in Literacy in Medieval Celtic Societies, ed. Huw Pryce (Cambridge, 1998), 62-82; Máirín Ní Dhonnchadha, "The Beginnings of Irish Vernacular Literary Tradition," in L'Irlanda e gli Irlandesi nell'alto Medioevo (Spoleto, 2010), 533-97.

Traditio 71 (2016), 33-61

(C) Fordham University, 2016

doi:10.1017/tdo.2016.5 
the fact that both societies had to learn Latin as a second language. The conversion of the Gaels began in the fifth century, and the Anglo-Saxons were converted during the course of the seventh century. In both societies, the Church played an active role in the dissemination of learning and literacy in Latin as well as in their vernaculars.

This study will examine Anglo-Saxon and Gaelic attitudes towards vernacular poets and their literary culture starting from early accounts by clerics writing in Latin for ecclesiastical purposes. Both societies privileged ecclesiastical learning in the earliest phases of their recorded cultures. The named vernacular poets in these Latin accounts became known outside of the immediate context of the accounts. It would appear, therefore, that both clerics recognized the contribution that vernacular poets could make to the Church and their wider societies. The focus of this study is on how Anglo-Saxon and Gaelic societies each treated these poets in their subsequent cultural histories using ca. 1200 as a notional time limit.

Muirchú maccu Machtheni, sometime ca. 690, was commissioned by Bishop Áed of Sletty [Sléibte] (d. 700) to write Vita Sancti Patricii. ${ }^{2}$ A short episode of this hagiographical work, set against the background of the conversion of the Gaels in the fifth century, tells how the professional poet Dubthach maccu Lugair, in the company of his understudy Fiacc Finn Sléibte, accepted the faith ahead of the others as Patrick endeavored to convert the pagan royal court of Lóegaire mac Néill at Tara. Muirchú treats as natural the presence at court of these high-status professionals without elaboration as though he expects his audience to know them already by their reputations.

Bede finished the Historia Ecclesiastica Gentis Anglorum in 731, several decades after Muirchú had written his Vita of Saint Patrick. ${ }^{3}$ Bede's Historia relates the conversion of the English people and the growth of the English church during the course of the seventh century. Bede describes Cædmon as a poet whose background, experience, and training apparently contradict his audience's expectations of a typical Anglo-Saxon poet. Nevertheless, Bede's account tells of the first recorded verse in Old English and how Cædmon's poetic talent was his

2 Ludwig Bieler, ed. and trans., The Patrician Texts in the Book of Armagh (Dublin, 1979), 62-123; David Howlett, Muirchú Moccu Macthéni's "Vita Sancti Patricii": Life of Saint Patrick (Dublin, 2006). It has been argued that Muirchú may have been a member of the Tuath Mochtaine, a people of the Plain of Macha (Mag Macha) which extended to the south and east of Armagh (Ard Macha): James F. Kenney, The Sources for the Early History of Ireland: Ecclesiastical (New York, 1929), 331; Edmund Hogan, Onomasticon Goedelicum Locorum et Tribuum Hiberniae et Scotiae (Dublin, 1910), 652. However, there is strong evidence of his Leinster origins as discussed by Anthony Harvey, "Muirchú and His remi cymba: Whence His Latin and Its Wordstore?" Peritia 27 (forthcoming). This article places Muirchú's Latin vocabulary and style in the context of other Hiberno-Latin writers.

3 Bertram Colgrave and R. A. B. Mynors, eds., Bedes's Ecclesiastical History of the English People (Oxford, 1969); hereafter referred to as HE [Historia Ecclesiastica]. 
gateway into religious life. We must consider the possibility that Bede was conscious of Gaelic precedence in his own portrayal of a vernacular poet's contribution to the early Church. ${ }^{4}$

These two Latin accounts are separated by roughly forty years with Muirchú being the earlier of the two. The events that Bede describes are removed from his time of writing by, perhaps, no more than forty-five to seventy-five years, which means that he could have relied on eyewitnesses. ${ }^{5}$ Muirchú, alternatively, is recreating purported events that were more than two centuries previous to his own time of writing. Some evidence suggests, as will be shown, that Muirchú was writing about persons whose reputations were already established.

While there are similarities in how these vernacular poets are treated in their respective cultural histories, it is the contrasts that may reveal the most about the societies that produced them. An important contrast would appear to be the formal recognition of social rank of poets in the law tracts among the Gaels. Anglo-Saxon records provide no equivalence. In order to trace Cædmon's biography, we never depart from Bede's Historia Ecclesiastica and learn nothing new about Cædmon outside of Bede's account. However, in the self-reflective Gaelic literary tradition we must search beyond Muirchú's Vita of Patrick and access other hagiographies, law tracts, martyrologies, genealogies, and poems in order to fill out the portraits of the poets Dubthach and Fiacc. Legal recognition of status may help explain the broad, intertextual acknowledgement of Gaelic poets in their cultural history.

An aspect of this study is to survey an array of information about poets and texts that is already well known by researchers in the early medieval period, specifically Anglo-Saxonists and Celticists. Inevitably, some will feel that certain subjects have been overemphasized while others have been underemphasized. Whatever the deficiencies in the broader comparisons, the focus of this study is to contrast the treatment of the named vernacular poets in the accounts of Bede and Muirchú in the subsequent literary histories of their respective societies.

4 Bede's work is the most significant external source for early Gaelic cultural history. His consciousness of the contribution of the Gaels to early Anglo-Saxon culture is reflected in his relating of the success of the Iona mission to Northumbria and the biography of Bishop

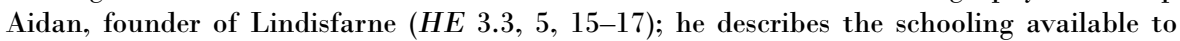
the English in Ireland (HE 3.27), specifically at Rath Melsigi (HE 3.27, 37; 4.3; 5.9-11); he provides the earliest surviving record of St. Fursa and his vision ( $H E$ 3.19); he details his respect for Abbot Adomnán of Iona (HE 5.15) and created an epitome of Adomnán's De locis sanctis, some of which he cited in his Historia Ecclesiastica (HE 5.16-17).

5 See, for example, Dennis Cronan, "Cæædmon's Audience," Studies in Philology 109 (2012): 333-63. Bede was made deacon (ca. 692) and then ordained priest (ca. 703) by John of Beverley who had trained at Whitby (HE 5.24). 


\section{Poets in Society}

Each society differed in how poets were integrated into the social structure. Recent research among Anglo-Saxon scholars has highlighted poets, the production of their works, their social positions, and their contributions to society. For example, Daniel O'Donnell has completed a thorough study of Cædmon's Hymn, placing it in the larger Anglo-Saxon and Germanic traditions, summarizing the search for analogues and sources, tracing its manuscript history, and editing the surviving versions of the hymn in its various dialects. ${ }^{6}$ In another wide-ranging study, Emily Thornbury has examined those who became poets in Anglo-Saxon literary cultural history, whether in Old English or Anglo-Latin, seeking to know their social backgrounds and functions within their communities. ${ }^{7}$ While she states that terms for poets, whether in Old English or Latin, reflected "relative privilege," she notes that those historical persons who created poetry were more likely to be referred to by other terms that reflected their social positions such as scribe, abbot, or bishop. This tendency not to refer to creators of poetry as "poets" may reflect the fact that "there is no solid evidence that a professional class of poets existed in Anglo-Saxon England." 9

Based on surviving records from both societies, it appears that Gaelic poets enjoyed higher social status than their Anglo-Saxon counterparts. Early Gaelic society was "hierarchical and inegalitarian," 10 and the law tracts lay "great stress on distinctions of rank and profession." 11 The chief distinctions in rank were between those who were nemed, a term which can be translated as "privileged," and those who were non-nemed. Anyone with nemed status had special privileges. Within the nemed social ranks and professions was the further distinction of those who were sóernemed ("noble nemed; a noble dignitary") and those who were dóernemed ("base nemed; a dependent professional"). ${ }^{12}$ The only profession with sóernemed status was the poet (fili), as will be discussed. ${ }^{13}$ All other professions were dóernemed or non-nemed. Some professions that enjoyed dóernemed status included lawyers (brithem and aigne), the physician (liaig), the woodworker (sáer), the blacksmith (gobae), and other craftsmen such as the silversmith (cerd) and coppersmith (umaige). Entertainers also figured as professionals, but only

6 Daniel Paul O'Donnell, Codmon's Hymn: A Multimedia Study, Archive and Edition (Cambridge, 2005). See further the essays in Allen J. Frantzen and John Hines, eds., Codmon's Hymn and Material Culture in the World of Bede (Morganstown, WV, 2007).

7 Emily V. Thornbury, Becoming a Poet in Anglo-Saxon England (Cambridge, 2014).

8 Ibid., 34.

9 Ibid.

10 Fergus Kelly, A Guide to Early Irish Law (Dublin, 1988), 7.

11 Ibid., 16.

12 Ibid., 9-10.

13 Ibid., 43. 
the harpist (cruit) achieved dóernemed status. All other entertainers were nonnemed and considered fodána ("subordinate professions"), such as the piper (cuislennach), the horn player (cornaire), the juggler (clesamnach), and the jester (fuirsire). ${ }^{14}$

Professional poets among the Gaels participated in a system of formal training or apprenticeship that could include hereditary privileges for those descended from poets. There were hierarchies of poets with named divisions that helped designate the amount of training, skills and qualifications, honor-price, and privileges — such as size of retinues and freedom to travel - that each poet had attained. ${ }^{15}$ Many details are found in four eighth-century vernacular law tracts that adumbrate the status of poets in the larger society. ${ }^{16}$ What is probably the most recent of them, Uraicecht na Ríar ("Primer of the Stipulations"), ${ }^{17}$ is devoted entirely to poets, their grades, their qualifications, their training, and more. The earliest of the four, Bretha Nemed ("Judgments of Privileged Persons"), is dated to the second quarter of the eighth century, ${ }^{18}$ composed sometime after the Collectio canonum Hibernensis. ${ }^{19}$ Bretha Nemed distinguishes four

14 Ibid., 51-65. For a discussion of distinctions in woodwind instruments, see Jacopo Bisagni, "Flutes, Pipes, or Bagpipes? Observations on the Terminology of Woodwind Instruments in Old and Middle Irish," in Early Medieval Ireland and Europe: Chronology, Contacts, Scholarship; A Festschrift for Dáibhí Ó Cróinín, ed. Pádraic Moran and Immo Warntjes (Turnhout, 2015), 343-94.

15 For discussion of some of the named poetic ranks, such as ollam, ánsruth, clí, cano, dos, macfuirmid, fochloc, see Liam Breatnach, ed., Uraicecht na Ríar: The Poetic Grades in Early Irish Law (Dublin, 1987), 80-83.

16 The social status of poets is briefly outlined in Kelly, Guide to Irish Law, 43-49. The knowledge that the Gaelic poet (fili) purportedly controlled included meters, narrative tales, genealogies, law, and even prophecy. For some studies that attempt to convey that breadth, see Gerard Murphy, "Bards and Filidh," Éigse 2 (1940): 200-207; Seán Mac Airt, "Filidecht and Coimgne," Ériu 18 (1958): 139-52; and Tomás Ó Cathasaigh, "Aspects of Memory and Identity in Early Ireland," in Narrative in Celtic Tradition: Essays in Honor of Edgar M. Slotkin, ed. Joseph M. Eska (Hamilton, NY, 2011), 201-16.

17 Breatnach, Uraicecht na Ríar, 77 (for dating to "the second half of the eighth century"); Kelly, Guide to Irish Law, 268 (§13); Liam Breatnach, A Companion to the Corpus Iuris Hibernici (Dublin, 2005), 320-21.

18 Idem, "Canon Law and Secular Law in Early Ireland: The Significance of Bretha Nemed," Peritia 3 (1984): 439-59, at 442-44 for dating. According to the etiological legend this law tract was composed by three kinsmen, one of whom, Máel Tuile ua Búirecháin, was a poet. There are two related tracts called Bretha Nemed, one designated toísech ("early"), and one dédenach ("late"). See further, Kelly, Guide to Irish Law, 268-69 (§14) (toísech), (§15) (dédenach); Breatnach, Uraicecht na Ríar, 20-57; idem, Companion, 184-91 (§5.15) (dédenach), (§5.16) (toúsech).

19 For dating limits of the collectio, see Paul Russell, "What Was Best of Every Language': The Early History of the Irish Language," in A New History of Ireland, ed. Dáibhí Ó Cróinín, vol. 1, Prehistory and Early Ireland (Oxford, 2005), 445; and Thomas CharlesEdwards, Early Christian Ireland (Cambridge, 2000), 265. 
divisions of those who are sóernemed, that is, those who occupied the highest rank of the Gaelic social hierarchy. They are the "ecclesiastical scholar, churchman, lord, poet" (ecnae, eclais, flaith, fili). ${ }^{20}$ Note that top-ranking poets were sóernemed and shared the highest social status along with elite secular and religious leaders. The remaining two law tracts, Uraicecht Becc ("Small Primer") ${ }^{21}$ and Míadslechtae ("Sections on Rank"), ${ }^{22}$ were probably composed after the middle of the eighth century. While each of these law tracts differs with regard to specific details, they all agree in the esteem accorded the poets as a professional, learned class within the Gaelic social hierarchy. Anglo-Saxon poets did not enjoy such formal, legal recognition.

The advantages that accrued to those poets who worked in cooperation with the bilingual world of the ecclesiastical intelligentsia are evident in both societies. ${ }^{23}$ For example, named Anglo-Saxon poets, who may or may not have composed in Old English, were usually sophisticated, literate nobles or churchmen. Aldhelm (d. 709), from whom no vernacular poems survive, was a Latin poet and scholar who attained the ranks of abbot and bishop. ${ }^{24}$ The tradition that he composed Old English verse was reported by William of Malmesbury in the twelfth century, after the Anglo-Saxon period had ended. ${ }^{25}$ Bede (d. 735) was

${ }^{20}$ Liam Breatnach, "The First Third of the Bretha Nemed Toísech," Ériu 40 (1989): 1-40, at $8-9(§ 1)$.

21 Eoin MacNeill, "Ancient Irish Law: The Law of Status or Franchise," Proceedings of the Royal Irish Academy 36C (1921-24): 272-81; Kelly, Guide to Irish Law, 267; Breatnach, Uraicecht na Ríar, 3-19; idem, Companion, 315-18.

22 MacNeill, "Law of Status or Franchise," 311-13; Kelly, Guide to Irish Law, 267; Breatnach, Uraicecht na Ríar, 19; idem, Companion, 264-65.

23 Emily Thornbury noted four social roles among Anglo-Saxons that were likely to produce poets. They were teachers, scribes, musicians, and courtiers: Thornbury, Becoming a Poet (n. 7 above), 39. She has drawn up a list of fifty persons from the Anglo-Saxon period to whom authorship of poems can be attributed. Most composed in Latin, but seven may have composed in Old English: ibid., 243-47. No such thorough research exists for the early Gaelic period, but Elva Johnston has identified in an appendix nearly 200 persons from the annals 797-1002 who have titles, including poet, denoting literacy and implying the potential to produce poetry. The list includes scriba, sapiens, ecnaid, fer léigind, suí, fili, etc.: Elva Johnston, Literacy and Identity in Early Medieval Ireland (Woodbridge, 2013), 177-202.

24 Thornbury, Becoming a Poet, 135-59, 243-44. In order to survey Aldhelm's poetic works in Anglo-Latin, see Michael Lapidge and James L. Rosier, trans., with an appendix by Neil Wright, Aldhelm: The Poetic Works (Cambridge, 1985); Andy Orchard, The Poetic Art of Aldhelm (Cambridge, 1994). For essays that emphasize Aldhelm's Carmen rhythmicum, see Katherine Barker and Nicholas Brooks, eds., Aldhelm and Sherborne: Essays to Celebrate the Founding of the Bishopric (Oxford and Oakville, CT, 2010).

25 M. Winterbottom, ed. and trans., William of Malmesbury Gesta Pontificum Anglorum: The History of the English Bishops, 2 vols. (Oxford, 2007), 1:506-7 (bk. 5 [§190]). See the cogent remarks about both Cædmon and Aldhelm in the context of William of Malmesbury by Roberta Frank, "The Search for the Anglo-Saxon Oral Poet," Bulletin of the John Rylands 
himself an influential Latin scholar and priest. ${ }^{26}$ We learn that Bede knew Old English poetry ("erat doctus in nostris carminibus") only posthumously in a letter by one of his pupils who described his last days. ${ }^{27}$ The poems of Cynewulf (ninth-tenth century) reveal a literate cleric working among his books to create devotional texts, but we acknowledge this most prolific of Old English named poets only because he identified himself with runes in four of his poems. ${ }^{28} \mathrm{King}$ Alfred (d. 899), who was of the highest social rank, engaged his court scholars in a project of "translating" into Old English from selected Latin originals for a literate, ecclesiastical audience. ${ }^{29}$

When we examine Gaelic society for named vernacular poets, we find many of them cooperating with the Church as we saw among the named Anglo-Saxon poets. Colmán mac Lénéni (d. 606) began his career as a professional praise poet but later entered religious life and founded the ecclesiastical site at Cloyne, Co. Cork. ${ }^{30}$ Among surviving fragments of his work are examples of religious

University Library of Manchester 75 (1993): 11-36, at 30-34. It has been argued that the formulaic quality of his Latin hexameters shows that Aldhelm was familiar with Old English verse: Michael Lapidge, "Aldhelm's Latin Poetry and Old English Verse," Comparative Literature 31 (1979): 209-31.

26 Thornbury, Becoming a Poet, 183-97, 244-45. The theme of Bede as poet and intellectual is vast, but few scholars treat him as a vernacular poet: Michael Lapidge, Bede the Poet, Jarrow Lecture (Newcastle upon Tyne, 1993). Some examples of research covering the breadth of his scholarship include Gerald Bonner, ed., Famulus Christi: Essays in Commemoration of the Thirteenth Centenary of the Birth of the Venerable Bede (London, 1976); and George Hardin Brown, Bede the Venerable (Boston, 1987); for a recent collection of analytical essays, see Scott DeGregorio, ed., Innovation and Tradition in the Writings of the Venerable Bede (Morgantown, WV, 2006); and idem, ed., The Cambridge Companion to Bede (Cambridge, 2010).

27 Colgrave and Mynors, HE (n. 3 above), 579-87 (Cuthbert's Epistola de obitu Bedae), quoted at 580 .

28 Thornbury, Becoming a Poet, 120-35, 245; for an overview of this most prolific of named Old English poets, see Daniel G. Calder, Cynewulf(Boston, 1981); Earl R. Anderson, Cynewulf: Structure, Style, and Theme in His Poetry (London and Toronto, 1983); and Robert E. Bjork, ed., Cynewulf: Basic Readings (New York, 1996), reprinted as The Cynewulf Reader (London and New York, 2001). For a work that adds a fifth poem to the canon, see Robert E. Bjork, The Old English Poems of Cynewulf (Cambridge, MA, 2013).

29 Thornbury, Becoming a Poet, 22-23, 61-63, 223-25, 244; see further "Extracts from the Writings of King Alfred," in Alfred the Great: Asser's "Life of King Alfred" and Other Contemporary Sources, trans. Simon Keynes and Michael Lapidge (New York, 1983), 123-60; Greenfield and Calder, "The Alfredian Translations and Related Ninth-Century Texts," in New Critical History (n. 1 above), 38-67; Timothy Reuter, ed., Alfred the Great: Papers from the Eleventh-Century Centenary Conferences (Aldershot, 2003); and Susan Irvine and Malcolm R. Godden, eds. and trans., The Old English Boethius with Verse Prologues and Epilogues Associated with King Alfred (Cambridge, MA, 2012).

30 Colin Ireland, "The Poets Cædmon and Colmán mac Lénéni: The Anglo-Saxon Layman and the Irish Professional," in Heroic Poets and Poetic Heroes in Celtic Traditions: A Festschrift for Patrick K. Ford, ed. Joseph Falaky Nagy and Leslie Ellen Jones (Dublin, 2005), 172-82. For earlier works about Colmán, see Rudolf Thurneysen, "Colmān mac 
verse as well as encomia. ${ }^{31}$ Abbot Adomnán of Iona (d. 704) composed in both Latin and Gaelic and has poetry as well as prose in both languages attributed to him. ${ }^{32}$ His work De locis sanctis was well known among the Anglo-Saxons and was disseminated by both King Aldfrith and Bede. ${ }^{33}$ Óengus mac Óengobann (fl. 830 ), whose floruit coincides with a productive period of Gaelic literary activity, ${ }^{34}$ composed the versified martyrology Félire Óengusso which included local saints as well as those from the wider Christian world. ${ }^{35}$ Cormac mac Cuilennáin (d. 908), a close contemporary of King Alfred, was king-bishop of Cashel and has several important texts attributed to him, including the learned Sanas Cormaic ("Cormac's Glossary"). ${ }^{36}$ This brief list of Gaelic poets could easily be expanded. ${ }^{37}$

Lēnēni und Senchān Torpēist," Zeitschrift für celtische Philologie 19 (1933): 193-209; and James Carney, "Three Old Irish Accentual Poems," Ériu 22 (1971): 23-80, at 63-65. For a work that identifies Colmán's kin group and puts him in the context of other Munster families, see Paul MacCotter, Colmán of Cloyne: A Study (Dublin, 2004). This latter work updates traditions about Colmán and his relationship with St. Brendan: ibid., 70-71.

31 For translations of the fragments by Donnchadh Ó Corráin, see MacCotter, Colmán of Cloyne, 129-32.

32 Vernacular poems attributed to him can be seen at James Carney, "A maccucáin sruith in tíag," Celtica 15 (1983): 25-41; and Thomas Owen Clancy and Gilbert Márkus, Iona: The Earliest Poetry of a Celtic Monastery (Edinburgh, 1995), 164-76 ("Colum Cille co Día domm eráil").

33 Denis Meehan, ed., Adamnan's De locis sanctis (Dublin, 1958). Bede helped disseminate this work among the Anglo-Saxons (HE 5.15-17). Adomnán was also a hagiographer: Alan Orr Anderson and Marjorie Ogilvie Anderson, eds., rev. Marjorie Ogilvie Anderson, Adomnán's Life of Columba (Oxford, 1991). He promoted an important law: Kuno Meyer, ed., Cáin Adamnáin: An Old-Irish Treatise on the Law of Adamnan, Anecdota Oxoniensia (Oxford, 1905); Thomas O'Loughlin, ed., Adomnán at Birr, AD 697: Essays in Commemoration of the Law of the Innocents (Dublin, 2001). For a recent collection of essays, see Adomnán of Iona: Theologian, Lawmaker, Peacemaker, ed. Jonathan M. Wooding et al. (Dublin, 2010).

34 Pádraig Ó Fiannachta, "Spioradáltacht Thamhlachta," in Léachtai Cholm Cille VIII: Ár nDúchas Creidimh, ed. idem (Maynooth, 1977), 19-39; Westley Follett, Céli Dé in Ireland: Monastic Writing and Identity in the Early Middle Ages (Woodbridge, 2006), chap. 4, "A Survey of Texts Attributed to Céli Dé," 100-170.

35 Whitley Stokes, ed., Félire Óengusso Céli Dé: The Martyrology of Oengus the Culdee (London, 1905; repr. Dublin, 1984); Follett, Céli Dé in Ireland, 117-21; Pádraig Ó Riain, "The Tallaght Martyrologies, Redated," Cambridge Medieval Celtic Studies 20 (1990): 21-38; idem, "The Martyrology of Óengus: The Transmission of the Text," Studia Hibernica 31 (2000-2001): 221-42.

36 For a discussion of his contributions, see Máire Ní Mhaonaigh, "Cormac mac Cuilennáin: King, Bishop and "Wondrous Sage," Zeitschrift für celtische Philologie 58 (2011): 109-28. For an edition of an early text that is now attributed to him, see Liam Breatnach, "An Edition of Amra Senáin," in Sages, Saints and Storytellers: Celtic Studies in Honour of Professor James Carney, ed. Donnchadh Ó Corráin, Liam Breatnach, and Kim McCone (Maynooth, 1989), 7-31. For other texts that are associated with his name, see Pádraig Ó Riain, "The Psalter of Cashel: A Provisional List of Contents," Éigse 23 (1989): 107-30; and Paul Russell, "Dúil Dromma Cetta and Cormac's Glossary," Études celtiques 32 (1996): 147-74.

37 Some additional noteworthy vernacular poets from before ca. 900 include Beccán mac Luigdech (fl. 670) who composed poems about St. Columba; Fergus Kelly, "A Poem in Praise 


\section{Secular Vernacular Texts}

The surviving vernacular texts attributed to named, historical poets in both societies reveal their debt to the Church and its promulgation of Latinate learning. Literature in Old English is dominated by religious texts such as saints' lives, homilies, retellings of biblical texts, or other works that can be sourced in the Latinate tradition. Indeed, the emphasis on biblical and Latinate sources may help account for the lack of references to vernacular poets and their traditions in surviving Anglo-Saxon records.

Only a handful of secular texts survive and even fewer that deal with characters and events of the Germanic past that help adumbrate the functions and practices of poets. Three such poems are Beowulf, Widsith, and Deor. Beowulf takes its modern title from the main character and relates his three combats against extraordinary beings. ${ }^{38}$ Although the language of the text is Old English, the main action of the narrative occurs between Sweden and Denmark. The title Widsith names the poet. This catalog poem demonstrates that a poet was expected to know persons, peoples, and events that centered on, but extended beyond, the Germanic world. ${ }^{39}$ The title Deor also names the poet who describes himself as

of Columb Cille," Ériu 24 (1973): 1-34; idem, “Tiughraind Bhécáin," Ériu 26 (1975): 66-98; and Clancy and Márkus, Iona, 129-63. Cenn Fáelad sapiens (d. 679) is credited with a wide array of topics: Colin Ireland, "What Constitutes the Learning of a Sapiens?: The Case of Cenn Fáelad," Peritia 27 (forthcoming). Blathmac mac Con Brettan (fl. 760) composed religious poems: James Carney, The Poems of Blathmac son of Cú Brettan together with the Irish Gospel of Thomas and a Poem on the Virgin Mary (Dublin, 1964). Colcu ua Duinechda (d. 796) may have been known to Alcuin: Kuno Meyer, "Colcu úa Duinechda's Scúap Chrábaid, or Besom of Devotion," Otia Mersiana 2 (1900-1901): 92-105; and Tomás O'Sullivan, "Texts and Transmissions of the Scúap Chrábaid: An Old-Irish Litany in Its Manuscript Context," Studia Celtica Fennica 7 (2010): 26-47. Orthanach ua Coílláma (d. 839) mentioned secular heroes of the past in his religious work: Kuno Meyer, ed. and trans., Hail Brigit: An OldIrish Poem on the Hill of Alenn (Dublin, 1912); Proinsias Mac Cana, The Learned Tales of Medieval Ireland (Dublin, 1980), 102 and n92. Works by Máel Muru Othna (d. 887) helped form the basis for Lebor Gabála: John Carey, "In Search of Mael Muru Othna," in Clerics, Kings and Vikings: Essays on Medieval Ireland in Honour of Donnchadh Ó Corráin, ed. Emer Purcell et al. (Dublin, 2015), 429-39. Flannacán mac Cellaigh (d. 896), a king of Brega and another contemporary of King Alfred, wrote on saga heroes: Kathleen Mulchrone, "Flannacán mac Cellaich Rí Breg Hoc Carmen," Journal of Celtic Studies 1 (1949-50): 80-93. 38 R. D. Fulk, Robert E. Bjork, and John D. Niles, eds., Klaeber's Beowulf and the Fight at Finnsburg, 4th ed. (Toronto, 2008). For a noted translation that includes scholarly background discussion to the poem, see Seamus Heaney, trans., and Daniel Donoghue, ed., Beowulf: A Verse Translation (New York, 2002).

39 Joyce Hill, ed., Old English Minor Heroic Poems, 3rd ed. (Durham and Toronto, 2009), 14-17, 31-36, 44-46. For background to the contents, see John D. Niles, "Widsith and the Anthropology of the Past," Philological Quarterly 78 (1999): 177-213. For a translation, see Robert E. Bjork, ed. and trans., Old English Shorter Poems, vol. 2, Wisdom and Lyric (Cambridge, MA, 2014), 44-55. 
a scop and laments his loss of patronage. ${ }^{40}$ The poem refers to characters and episodes from Germanic myth and history. ${ }^{41}$ Widsith and Deor share with Beowulf the characteristics of Old English poems that reflect Germanic traditions about named characters from myth, legend, and history. They also portray functioning poets, implying their professional status and reliance on patronage. ${ }^{42}$ However, none of the three poems is firmly placed in the English landscape or unequivocally depicts a specifically Anglo-Saxon, as opposed to a general Germanic, context. ${ }^{43}$

Early Gaelic literature preserves a wider array of genres, including those genres present in Old English, but the secular texts dealing with traditional characters and themes are more numerous. For example, many tales deal with the Ulster heroes, such as Táin Bó Cuailnge, often translated as "The Cattle Raid of Cooley." ${ }^{44}$ It survives in various recensions which relate the single combats of Cú Chulainn against the warriors of the armies invading Ulster. Scéla Mucce meic Dathó ("The Tidings of Mac Dathó's Pig") is often treated as a parody of the heroic ethos. ${ }^{45}$ Many tales are concerned with mythic themes. For example, Tochmarc Étaine ("The Wooing of Étaín") follows Midir's pursuit of the beautiful faerie woman Étaín through various incarnations. ${ }^{46}$ Cath Maige Tuired ("The Second Battle of Mag Tuired") recounts the battle between the Túatha Dé Danann and the Fomoire, supernatural races of pre-Christian Ireland. ${ }^{47}$ Many tales are based on historical characters of the seventh century, though the historicity of the tales may be queried. Compert Mongáin ("The Conception of Mongán")

40 Note that Thornbury's observation that in Anglo-Saxon society those who created poetry did not describe themselves as poets refers to historical persons. The scop Deor cannot be placed historically or geographically: Thornbury, Becoming a Poet (n. 7 above), 35. Aldhelm expresses pride in his Latin, not vernacular, poetry: ibid., 32-33.

41 Kemp Malone, ed., Deor (Exeter, 1977); Hill, Minor Heroic Poems, 17-22, 37-38, 47-49. For a translation, see Bjork, Old English Shorter Poems, 2:98-101.

42 That such practices existed during the Anglo-Saxon period in Britain is shown by the list of named Scandinavian poets and their patrons, most of whom can be dated and located: Thornbury, Becoming a Poet, 248-49. Unfortunately, no such evidence survives for AngloSaxon vernacular poets.

43 By contrast, anonymous vernacular poems such as the Battle of Brunanburh, the Battle of Maldon, and the Durham poem all use personal and place names that situate the poems on the island of Britain during the Anglo-Saxon period.

44 Cecile O'Rahilly, ed. and trans., Táin Bó Cúailnge, Recension I (Dublin, 1976); eadem, ed. and trans., Táin Bó Cúalnge from the Book of Leinster (Dublin, 1967). For background, see J. P. Mallory, ed., Aspects of the Táin (Belfast, 1992).

45 Rudolf Thurneysen, ed., Scéla Mucce meic Dathó (Dublin, 1935). For a translation, see Jeffrey Gantz, Early Irish Myths and Sagas (Harmondsworth and New York, 1981), 179-87.

46 Osborn Bergin and R. I. Best, "Tochmarc Étaíne," Ériu 12 (1934-38): 137-96. For a brief outline, see Myles Dillon, Early Irish Literature (Chicago, 1948; repr. Dublin, 1994), $54-58$.

47 Elizabeth A. Gray, ed. and trans., Cath Maige Tuired: The Second Battle of Mag Tuired (Naas, 1982). For a brief discussion, see Dillon, Early Irish Literature, 58-62. 
is set in the context of Áedán mac Gabráin's battles against the Anglo-Saxons that were known to Bede $\left(H E\right.$ 1.34). ${ }^{48}$ Mongán mac Fiachnai died in $625 .{ }^{49}$ Scéla Cano meic Gartnáin ("Tidings of Cano son of Gartnán”) preserves early features of the Tristan legend. ${ }^{50}$ Cano mac Gartnáin died in $688 .{ }^{51}$ Some tales seem intended as Christian allegories in traditional settings, such as Immram Brain ("The Voyage of Bran") in which Bran is taken on a trip to a deathless world across the sea. ${ }^{52}$ In Echtrae Chonnlai ("The Adventure of Connlae") the hero, who is the son of the famous king Conn Cétchathach, ${ }^{53}$ abandons the courtly life for a sinless, deathless "otherworld" similar to that described in Immram Brain. These Gaelic texts all mention identifiable locations on the landscapes of Ireland and/or Britain. All of the vernacular, secular texts named above, in either language, are anonymous. ${ }^{54}$

We have surveyed, briefly and broadly, poets and their works in Anglo-Saxon and Gaelic societies. We should now turn to the specific accounts of vernacular poets by the ecclesiastical writers Bede and Muirchù.

\section{Bede's Account of Cedmon}

Bede's account of Cædmon's composition of a poem in praise of the Creator in book 4, chapter 24 of the Historia Ecclesiastica is acknowledged as the earliest description of surviving literature in the Old English vernacular. ${ }^{55}$ The event

48 Nora White, ed. and trans., Compert Mongáin and Three Other Early Mongán Tales (Maynooth, 2006), 71-72, 78-79, 86-115.

49 Seán Mac Airt and Gearóid Mac Niocaill, eds., The Annals of Ulster (to A.D. 1131) (Dublin, 1983), 112-13.

50 D. A. Binchy, ed., Scéla Cano meic Gartnáin (Dublin, 1963). For discussions, see Myles Dillon, The Cycles of the Kings (London and New York, 1946), 79-83; and James Carney, Studies in Irish Literature and History (Dublin, 1955), 202-4, 215-17.

51 Mac Airt and Mac Niocaill, Annals of Ulster, 150-51.

52 A. G. van Hamel, ed., Immrama (Dublin, 1941), 1-19; Kuno Meyer, trans., The Voyage of Bran (London, 1895); Séamus Mac Mathúna, ed. and trans., Immram Brain: Bran's Journey to the Land of the Women (Tübingen, 1985).

53 Kim McCone, ed. and trans., Echtrae Chonnlai and the Beginnings of Vernacular Narrative Writing in Ireland (Maynooth, 2000). For arguments that this text should be read allegorically, see Kaarina Hollo, "Allegoresis and Literary Creativity in Eighth-Century Ireland: The Case of Echtrae Chonnlai," in Narrative in Celtic Tradition: Essays in Honor of Edgar M. Slotkin, ed. Joseph F. Eska (Hamilton, NY, 2011), 117-28.

54 There is evidence that knowledge of narrative texts came under the purview of the fili. For example, in Uraicecht na Ríar, the ollam ("highest ranking poet") had 350 compositions (dréchta): Breatnach, Uraicecht na Ríar (n. 11 above), 102-3 (§2). These are often taken to signify the purported 350 narratives ostensibly preserved in the tale lists: Mac Cana, Learned Tales (n. 28 above). An early eighth-century tale about Mongán mac Fíachnai (d. 625) tells that his poet Forgoll fili related a story to Mongán every night of the winter, that is, between Samain and Beltaine: White, Compert Mongáin, 73 (Gaelic), 79 (English) (§1).

55 Colgrave and Mynors, HE (n. 3 above), 414-21. 
took place at the monastery of Whitby on the Cleveland coast during the abbacy of Hild between 657 and 680 , or a few years later, perhaps up to $684 .{ }^{56}$ Bede's Latin account is the longest and most detailed of how a poet in the AngloSaxon world pursued his craft. Since it is the earliest and most complete account of an Anglo-Saxon poet, critics have used it as the leading example of the methods and techniques employed by those poets who composed in Old English. It is by coupling Bede's account with descriptions of practicing poets from Old English poems that critics have attempted to recreate a picture of the functioning Anglo-Saxon poet. ${ }^{57}$ In the context of the present argument, we see Bede's attempt to elevate Cædmon as the first recorded vernacular poet among the Anglo-Saxons. The following extracts from Bede's account are most pertinent to the discussion.

In huius monasterio abbatissae fuit frater quidam diuina gratia specialiter insignis, quia carmina religioni et pietati apta facere solebat, ita ut, quicquid ex diuinis litteris per interpretes disceret, hoc ipse post pusillum uerbis poeticis maxima suauitate et / conpunctione conpositis in sua, id est Anglorum, lingua proferret. Cuius carminibus multorum saepe animi ad contemtum saeculi et appetitum sunt uitae caelestis accensi. Et quidem et alii post illum in gente Anglorum religiosa poemata facere temtabant, sed nullus eum aequiperare potuit. Namque ipse non ab hominibus neque per hominem institutus canendi artem didicit, sed diuinitus adiutus gratis canendi donum accepit. Vnde nil umquam friuoli et superuacui poematis facere potuit, sed ea tantummodo, quae ad religionem pertinent, religiosam eius linguam decebant. Siquidem in habitu saeculari usque ad tempora prouectioris aetatis constitutus, nil carminum aliquando didicerat.

In the monastery of this abbess there was a certain brother who was specially marked out by the grace of God, so that he used to compose godly and religious songs; thus, whatever he learned from the holy Scriptures by means of interpreters, he quickly turned into extremely delightful and moving poetry, in English, which was his own tongue. By his songs the minds of many were often inspired to despise the world and to long for the heavenly life. It is true that after him other Englishmen attempted to compose religious poems, but none could compare with him. For he did not learn the art of poetry from men nor through a man but he received the gift of song freely by the grace of God. Hence he could never compose any foolish or trivial poem but only those which were concerned with devotion and so were fitting for his devout tongue to utter. He had lived in the secular habit until he was well advanced in years and had never learned any songs. ${ }^{58}$

56 For arguments supporting this later dating, see Dennis Cronan, "Cædmon's Hymn: Context and Dating," English Studies 91 (2010): 817-25. Others have argued that Cædmon's death, but not necessarily his composition, is covered by this later dating: O'Donnell, Cadmon's Hymn (n. 6 above), 10n6.

57 For discussions on and synopses of previous scholarship, see O'Donnell, Codmon's Hymn, 23-24, 45-46, 71-75; Thornbury, Becoming a Poet (n. 7 above), 5-8, 14-19.

58 Text and translation in Colgrave and Mynors, HE, 414-15. 
Bede was eager to show the piety and faith of his subject. He stressed the divine nature of Cædmon's inspiration, how his poetic gift was used to bring others to the faith, and how Cædmon met an exemplary death of which this pious ex-layman himself had prior knowledge. ${ }^{59}$

\section{Coedmon among Poets}

Bede relates that Cædmon never sang at convivia and, once, having left the others at the gathering, went off to a cattle byre where it was his duty to watch over the livestock. As he slept, a voice commanded him to compose a song in praise of the Creator. The song he composed, known as his Hymn, was approved at the monastery "in the presence of a number of the more learned men." 60 The examination by "more learned men" that Cædmon had to submit to can be compared to the eighth-century Gaelic law tract Uraicecht na Ríar which portrays the official approval process for a student poet:

Céist, cía cruth do-berar grád for filid? Ní hansae, taisbénad a dréchtae do ollamain -7 biit na secht ngráda fis occa -7 gaibthi in rí inna lángrád, inid-focladar int ollam asa dréchtaib...

How is a grade conferred on a poet? Not difficult; he shows his compositions to an ollam - and he has the seven grades of knowledge - and the king receives him in his full grade, in which the ollam declares him to be on the basis of his compositions ... ${ }^{1}$

The ollam filed was the highest grade of poet in Gaelic society. Once the ollam approved the student poet's accomplishments, the king could receive him into society at the appropriate poetic grade. After his examination, Cædmon was able to produce more verses on biblical and religious topics when they were recited to him. No one could do this better than he, and the abbess urged him to take monastic vows, which he did.

When we contrast Cædmon with named Old English poets discussed above we have a different picture of a vernacular Anglo-Saxon poet. Bede is clear that Cædmon was a layman of advanced age, was of humble status, had no formal training in Old English poetry, and resisted performing in public. Nevertheless, Cædmon took monastic vows after demonstrating his divinely inspired poetic

59 Knowledge of one's own impending death is a topos in hagiography and its presence in the account suggests, as some have argued, that Bede was attempting to sanctify Cædmon: see G. Wieland, "Cædmon: The Clean Animal," American Benedictine Review 35 (1984): 194203, at 198; David Hugh Farmer, Oxford Dictionary of Saints, 5th ed. (Oxford, 2003), 83-84, s. v. Cædmon; and discussion in O'Donnell, Cadmon's Hymn, 17-9, 27-8, 44. Firm evidence that Cædmon was considered a saint is not recorded until the seventeenth century: E. G. Stanley, "St. Cædmon," Notes \& Queries, n.s., 45 (March 1998): 4-5.

60 "Multis doctioribus uiris praesentibus," Colgrave and Mynors, HE, 416-17. Concerning Cædmon's potential training, see O'Donnell, Cadmon's Hymn, 6-7, 37-38, 74.

61 Breatnach, Uraicecht na Ríar, 104-5 (§6). 
ability. Unlike for many Gaelic poets, we have no genealogical background for Cædmon. It has long been noted that his name is Brythonic, equivalent to the modern Welsh Cadfan. ${ }^{62}$ It is possible that his name reflects his ethnic background and, therefore, his outsider status among the Anglo-Saxons. ${ }^{63}$

Bede assures his readers that Cædmon knew nothing of poetry, despite his acknowledged presence at convivia. Bede had said that Cædmon "did not learn the art of poetry from men nor through a man but he received the gift of song freely by the grace of God." 64 Bede implies that Cædmon's gift of song was a divinely inspired gift. The notion of inspired poets is a commonplace among the Gaels with professional poets encouraging belief in their special status as inspired individuals. They even named techniques or skills to induce the phenomenon. ${ }^{65}$ The Gaels recognized that strong emotion, either deep sorrow or great joy, could produce poetic inspiration. ${ }^{66}$ For example, an early eighth-century text, the "Caldron of Poesy," identified fáilte déodae ("divine joy") as a source of inspiration, like that experienced by Cædmon, which can come from the grace of

62 As long ago as 1934 it was noted that this name was Celtic in origin: F. Holthausen, Altenglisches Etymologisches Wörterbuch (Heidelberg, 1934), 42, s. v. Cædmon; for linguistic details, see Kenneth Jackson, Language and History in Early Britain (Edinburgh, 1953), 554. Ute Schwab had noted that Cædmon may have been bilingual which hints at his hesitancy to perform in public: Cadmon (Messina, 1972), 48. See further references in O'Donnell, Coedmon's Hymn, 3 and n.

63 Kenneth Jackson has noted that populations of Brythonic-speaking peoples survived in the Pennines and Yorkshire Moors after the Anglo-Saxons had occupied the lower lands around them: Jackson, Language and History, 197. He also argued, based on place-name evidence, that an unabsorbed Brythonic-speaking population existed in the Cleveland area, near Whitby, during the period under discussion: Kenneth Jackson, "Angles and Britons in Northumbria and Cumbria," in Angles and Britons: O'Donnell Lectures (Cardiff, 1963), 60-84, at 67.

64 "Ipse non ab hominibus neque per hominem institutus canendi artem didicit, sed diuinitus adiutus gratis canendi donum accepit." Colgrave and Mynors, HE, 414-15. Adherents of the oral-formulaic method of composition for Old English verse in the case of Cædmon contradict Bede here because they argue that Cædmon learned by listening to others, but these arguments are seldom advanced anymore: see Ireland, "Cædmon and Colmán mac Lénéni" (n. 30 above), 175n14; and O'Donnell, Caedmon's Hymn, 3-4, 23-24, 45, 60, 67-68, $106-7$.

65 One of the skills claimed by poets was called imbas forosna ("encompassing knowledge which illuminates"): Kelly, Early Irish Law (n. 10 above), 44-45. For a fuller discussion, see John Carey, "Three Things Required of a Poet," Ériu 48 (1997): 41-58. For a translation of a passage from Sanas Cormaic, discussed above as a text attributed to Cormac mac Cuilennáin, that purports to describe the process of imbas forosna, see Patrick K. Ford, trans., The Celtic Poets: Songs and Tales from Early Ireland and Wales (Belmont, MA, 1999), xxiii-xxv (discussion), 46-47 (translation).

66 A performance recorded in Beowulf, attributed to a gomela Scilding ("an old Scilding") that many equate with King Hroðgar, results, at least partially, from the emotions of the performer: Fulk, Bjork, and Niles, Klaeber's Beowulf (n. 38 above), 71-72, lines 2105-14, 233-34 (discussion). 
God. ${ }^{67}$ Thus Gaelic society recognized that poetic inspiration could come to any person in the right circumstances, regardless of a lack of training or inherited skills.

Furthermore, Bede said that Cædmon "had lived in the secular habit until he was well advanced in years and had never learned any songs." 68 Bede deliberately distanced Cædmon from secular Anglo-Saxon poetic practices as we understand them and from any notion of formal training. But he emphasized the worthiness of Cædmon's poetic topics for inclusion in the ambit of the Church.

Canebat autem de creatione mundi et origine humani generis / et tota Genesis historia, de egressu Israel ex Aegypto et ingressu in terram repromissionis, de aliis plurimis sacrae scriptura historiis, de incarnatione dominica, passione, resurrectione et ascensione in caelum, de Spiritus Sancti aduentu et apostolorum doctrina;

He sang about the creation of the world, the origin of the human race, and the whole history of Genesis, of the departure of Israel from Egypt and the entry into the promised land and of many other of the stories taken from the sacred Scriptures: of the incarnation, passion, and resurrection of the Lord, of His ascension into heaven, and of the coming of the Holy Spirit and the teaching of the apostles. ${ }^{69}$

It is uncanny how Bede's list of Cædmon's topics could have anticipated so astutely the surviving corpus of Old English verse. Bede says that Cædmon was instructed in sacred history and doctrine by those who were more learned. Thus he converted the Latinate subjects they taught him into melodious verse in the vernacular. His merit as a poet and, by extension, his value to the Church and its project of conversion, are confirmed when "his teachers became in turn his audience." $" 70$

The fact that some modern critics accept Cædmon's inspired gift as a "miracle" reveals the mythic qualities of Bede's account. ${ }^{71}$ Bede never called Cædmon's newly realized talents a miracle, although he emphasized, as noted above, that they were received "freely by the grace of God," thus supporting Bede's desire to elevate Cædmon as a pious individual. Bede had no hesitation in talking

67 Liam Breatnach, "The Caldron of Poesy," Ériu 32 (1981): 45-93, at 68-69 (§12); P. L. Henry, "The Caldron of Poesy," Studia Celtica 14-15 (1979-80): 114-28, at 125; Johan Corthals, "Decoding the "Caldron of Poesy," Peritia 24-25 (2013-14): 74-89, at 80n31. 68 "In habitu saeculari usque ad tempora prouectioris aetatis constitutus, nil carminum aliquando didicerat," Colgrave and Mynors, HE, 414-15. The person who gives up a secular lifestyle for a religious one is called an athláech ("ex-layman") in Gaelic. Several examples can be cited with Colmán mac Lénéni being one of the most famous, as noted in a text of ca. 700 translated by Vernum Hull, "Conall Corc and the Corco Luigde," Publications of the Modern Languages Association of America 62 (1947): 887-909, at 900; for an overview of Colmán’s career, see Ireland, "Cædmon and Colmán mac Lénéni," 176-80.

69 Colgrave and Mynors, HE, 418-19.

70 "Doctores suos uicissim auditores sui faciebat." Colgrave and Mynors, HE, 418-19.

71 O'Donnell, Cadmon's Hymn, 4-12, 25-28. 
about miracles, but when he did so he unequivocally called them miracles. ${ }^{72}$ For example, Bede took several chapters to describe miracles attributed to King Oswald and to Bishop Aidan. ${ }^{73}$ While Bede seemed intent on stressing Cædmon's sanctity, the attempt to elevate him to sainthood is, apparently, a late phenomenon. ${ }^{74}$ If there had been an earlier attempt to create a saint's cult around Cædmon, it never had any recorded success. ${ }^{75}$

Cædmon does not appear elsewhere in Anglo-Saxon literature, either in Latin or in Old English, outside of Bede's account. ${ }^{76} \mathrm{He}$ is not mentioned in the chronicles, law tracts, saints' lives, martyrologies, genealogies, homilies, sermons, or other narratives before the end of the Anglo-Saxon period. There is evidence that he was known further afield, however. For example, sometime in the first half of the twelfth century, after the Anglo-Saxon period, William of Malmesbury mentioned Cædmon, although he did not explicitly name him, as that monk buried at Whitby and to whom Bede referred who received the knowledge of song as a divine gift. ${ }^{77}$ It is clear that Bede's Historia Ecclesiastica is William's source for Cædmon. Likewise, on the Continent, the preface to the Old Saxon Heliand was influenced by Bede's account of Cædmon. But it has been argued that the Heliand's preface, at least in part, is not entirely medieval. Rather, some of it may have been produced by Renaissance antiquarians. ${ }^{78}$

In examining Bede's account of Cædmon, it has been instructive to compare aspects of Gaelic poetic traditions. We should now turn our attention to the account that mentions vernacular poets by Muirchú, a Gaelic hagiographer who also wrote in Latin.

72 Colgrave and Mynors, HE, xxxiv-xxxvi; Bertram Colgrave, "Bede's Miracle Stories," in Bede: His Life, Times, and Writings; Essays in Commemoration of the Twelfth Centenary of His Death, ed. A. H. Thompson (New York, 1966), 201-29; William D. McCready, Miracles and the Venerable Bede (Toronto, 1994).

73 Colgrave and Mynors, HE, 240-55 (HE 3.9-13; Oswald); 260-67 (HE 3.15-17; Aidan).

74 Stanley, "St. Cædmon" (n. 59 above), 4-5.

75 O'Donnell, Codmon's Hymn, 28, 44n7.

76 The surviving manuscripts of Bede's Historia Ecclesiastica and, therefore, of his account of Cædmon number well over one hundred. Twenty-one Old English copies of the Hymn itself have been recovered, all preserved as part of Bede's account: O'Donnell, Coedmon's Hymn, 78-97.

77 William of Malmesbury: "necnon et illius monachi quem divino munere scientiam cantus accepisse Beda refert," in Willelmi Malmesbiriensis monachii de gestis pontificum Anglorum, ed. N. E. S. A. Hamilton (London, Oxford, and Cambridge, 1870), 254; M. Winterbottom, ed. and trans., Gesta Pontificum Anglorum (n. 25 above), 1:386-87, iii.116.2.

78 Theodore M. Andersson, "The Caedmon Fiction in the Heliand Preface," Publications of the Modern Languages Association of America 89 (1974): 278-84; see further O'Donnell, Coedmon's Hymn, 17n17, 31-33, 97. 


\section{Muirchús Account of Dubthach and Fiacc}

Muirchú maccu Machtheni wrote a Life of St. Patrick around 690, several decades before Bede wrote the Historia Ecclesiastica. ${ }^{79}$ However, Muirchú, as a Gaelic cleric, does not seem conflicted by the presence of poets who composed in the vernacular for secular purposes. It is possible that Muirchú was familiar with the traditions about Colmán mac Lénéni, a poet who became a cleric and died ca. 606 and who was a contemporary of St. Columba. ${ }^{80}$ It would seem that Gaelic hagiographers were more accepting of vernacular poets than were their Anglo-Saxon or continental counterparts. For example, Adomnán in Vita Sancti Columbae, a late seventh-century text, relates that, while on a journey, sometime putatively in the last half of the sixth century, some monks ask Columba, after meeting up with a vernacular poet (scoticus poeta) named Crónán, "why did you not according to the custom ask for a song of his own composition, sung to a tune?"81 The saint had not made the request of Crónán because his prophetic ability allowed him to foresee the poet's impending violent death.

Muirchú's work was commissioned by another churchman, Bishop Áed of Sletty (Sléibte), who died in 700 as an anchorite. ${ }^{22}$ Sletty is on the River Barrow just north of the town of Carlow, which is itself only a few miles north

79 The broadest range of dates for the Vita Sancti Patricii is from 661, the start of Ségéne's bishopric of Armagh, and 700, the death of Bishop Áed of Sletty (Sléibte) who commissioned Muirchú to write the Vita: Bieler, Patrician Texts (n. 2 above), 1-2 for dating. David Howlett, based on previous Gaelic hagiographies and the ecclesiastical politics of Britain, suggested the period from 686 to 700 as the likely time for Muirchú to have composed: Howlett, Muirchú (n. 2 above), 182. Thomas Charles-Edwards argued that the decade of the 690 s, i.e., ca. 695 , made the most sense based on the obits of the bishops Ségéne and Áed: Charles-Edwards, Early Christian Ireland (n. 19 above), 439-40.

80 It seems likely that traditions about Colmán could have been known in Iona and, therefore by extension, in Northumbria: Ireland, "Cædmon and Colmán mac Lénéni" (n. 30 above), 174. In a recent article, Daniel McCarthy has argued from chronological evidence preserved in annals that Columba died in 593 and that the presently accepted date of 597 was created by Abbot Adomnán to suit hagiographical purposes. Since Bede repeats the 597 date, it implies that he learned it from an Iona source, perhaps Adomnán himself: McCarthy, "The Chronology of Saint Columba's Life," in Early Medieval Ireland and Europe (n. 14 above), 3-32.

81 “'Cur,' aiunt, 'a nobis regrediente Cronano poeta aliquod ex more suae artis canticum non postulasti modolabiliter decantari?"' Anderson, Life of Columba (n. 33 above), 76-77, i.42. The dating range for the Vita Columbae is from ca. 688 to ca. 704 when Adomnán died.

82 Bieler, Patrician Texts, 1:62-63; Howlett, Muirchú, 40-41. For some historical background about Bishop Áed, see Dáibhí Ó Cróinín, Early Medieval Ireland 400-1200 (London and New York, 1995), 156-57; and Charles-Edwards, Early Christian Ireland, 261-62, 428-29. For his obit, see Mac Airt and Mac Niocaill, Annals of Ulster (n. 49 above), 158-59. Áed probably died at Armagh after retiring as anchorite there, rather than at Sletty: Ó Cróinín, Early Medieval Ireland, 157; Donnchadh Ó Corráin, "Ireland c. 800: Aspects of Society," in idem, New History of Ireland (n. 19 above), 606. 
of Rath Melsigi, cited by Bede as an important school that trained Englishmen to become clerics at home in England and missionaries on the Continent. ${ }^{83}$ The Englishman Ecgberht at Rath Melsigi has been noted as a likely conduit for Gaelic literary and cultural traditions into Anglo-Saxon England. ${ }^{84}$ The names of both Bishop Áed of Sletty and Muirchú maccu Machtheni appear on the guarantor list for Cáin Adomnáin (known in Latin as Lex innocentium), a law promoted by Adomnán, abbot of Iona, in 697 and promulgated at Birr, Co. Offaly in the Irish midlands. ${ }^{85}$ Thus Muirchú's career reflects his relationships with Armagh in Ulster, with Sletty and Birr in Leinster, and with Iona in Scotland.

The episode involving Dubthach and Fiacc related by Muirchú is set on an Easter Day in the mid-fifth century at Lóegaire mac Néill's royal court at Tara in the Irish midlands. In typical hagiographical style, the protagonists' deeds are compared to those of biblical characters. St. Patrick had been attempting to convert the pagans at the court of King Lóegaire mac Néill in Tara. Patrick and his companions entered the court through closed doors, as Christ had done before them, in order to preach before all nations.

(1) Sequenti uero die, hoc est in die pascae, recumbentibus regibus et principibus et magis apud Loiguire — festus enim dies maximus apud eos erat —, manducantibus illis et bibentibus uinum in palatio Temoriae sermocinantibusque aliis et aliis cogitantibus de his quae facta fuerant, (2) sanctus Patricius quinque tantum uiris, ut contenderet et uerbum faceret de fide sancta in Temoria coram omnibus nationibus, hostiis claussis secundum id quod de Christo legitur uenit. (3) Adueniente ergo eo in caenacolum Temoriae nemo de omnibus ad aduentum eius surrexit praeter unum tantum, id est Dubthoch maccu Lugir, poetam optimum, apud quem tunc temporis ibi erat quidam adoliscens poeta nomine Feec, qui postea mirabilis episcopus fuit, cuius reliquiae adorantur hi Sleibti; (4) hic, ut dixi, Dubthach solus ex gentibus in honorem sancti Patricii surrexit et benedixit ei sanctus crediditque primus in illa die Deo et repputatum est ei ad iustitiam.

83 For the location of Sletty, see Hogan, Onomasticon (n. 2 above), 604. For background and location of Rath Melsigi, see Dáibhí Ó Cróinín, "Rath Melsigi, Willibrord, and the Earliest Echternach Manuscripts," Peritia 3 (1984): 17-49; Colin Ireland, "Some Analogues of the Old English Seafarer from Hiberno-Latin Sources," Neuphilologische Mitteilungen 92 (1991): 1-14; idem, "Where Was King Aldfrith of Northumbria Educated? An Exploration of Seventh-Century Insular Learning," Traditio 70 (2015): 29-73, at 34-35, 59-63.

84 Archibald A. M. Duncan, "Bede, Iona, and the Picts," in The Writing of History in the Middle Ages: Essays Presented to Richard William Southern, ed. R. H. C. Davis and J. M. Wallace-Hadrill (Oxford, 1981), 23-36, but Duncan also associates Ecgberht with Mayo of the Saxons; George Henderson, From Durrow to Kells: The Insular Gospel-books 650-800 (London, 1987), 91-97.

85 Meyer, Cáin Adomnáin (n. 33 above), 16-19; Máirín Ní Dhonnchadha, "The Guarantor List of Cáin Adomnáin," Peritia 1 (1982): 178-215, at 180, 192-93 (§25, Áed), 196 (§36, Muirchú); Máirín Ní Dhonnchadha, "The Law of Adomnán: A Translation," in O’Loughlin, Adomnán at Birr (n. 33 above), 57-58. 
(1) On the following day, that is Easter Day, when the kings and princes and druids were at table with Lóguire [Lóegaire] — for this was their greatest feast day eating and drinking wine in the palace of Tara, some of them talking, and others thinking about the things that had happened, (2) holy Patrick with only five companions entered through closed doors, as we read about Christ [John 20:19], in order to vindicate and to preach the holy faith at Tara before all the nations. (3) As he entered the banquet hall of Tara, none of them all rose in order to welcome him, except one man only [Deut. 4:35], Dubthach maccu Lug[a]ir, an excellent poet. With him was then in that place a young poet named Fíacc, who afterwards became a renowned bishop, whose relics are worshipped in Sléibte [Sletty]. (4) This Dubthach, as I have said, alone among the pagans rose in honour of holy Patrick, and the holy man blessed him, and he was the first on that day to believe in God, and it was counted to him for righteousness [Gen. 15:6]. ${ }^{86}$

Both secular, professional poets, Dubthach maccu Lugair and Fiacc Finn Sléibte, are brought to the faith by Patrick. The chief poet Dubthach was the only person among the pagans to rise in honor of Patrick to welcome him. Since the poet was the first to believe in God on that day, as Muirchú stated, "it was counted to him for righteousness," a phrase used in Genesis of the patriarch Abraham. Dubthach figures, along with Patrick, as a primary syncretist of indigenous legal practice and custom with Christian doctrine in the Gaelic law tracts, as we will see presently. ${ }^{87}$ Fiacc, the younger poet, as stated in Muirchú's account, became a bishop and founded the monastery at Sletty. It was one of Fiacc's successors in the bishopric at Sletty, Bishop Áed, who commissioned the Life of Patrick written by Muirchú. Thus Muirchú is drawing on the foundation narrative of Sletty in his anecdote about Dubthach and Fiacc in Vita Patricii.

Both Dubthach and Fiacc are mentioned in the Additamenta, a collection of brief documents in Latin and Old Gaelic found in the Book of Armagh, compiled by the mid-eighth century but whose contents are datable on linguistic criteria to ca. $700{ }^{88}$ One episode relates how Patrick asked Dubthach to suggest a candidate for ordination as bishop from among his pupils in Leinster. The man must be of a free lineage, without blemish, neither too wealthy nor too poor. Furthermore, the candidate should have but one wife who has borne him one child. ${ }^{89}$ Dubthach

86 Bieler, Patrician Texts (n. 2 above), 92-93. I have added clarifications in square brackets in the translation. For a revised, and closer, reading and translation of the text, see Howlett, Muirchú, 80-83.

87 The process was a long, complicated one involving the active participation of clerics, jurists, and poets. It is outlined and discussed briefly by Robin Chapman Stacey, Dark Speech: The Performance of Law in Early Ireland (Philadelphia, 2007), 55-59. Seminal studies that improved our modern understanding of the process are Donnchadh Ó Corráin, Liam Breatnach, and Aidan Breen, "The Laws of the Irish," Peritia 3 (1984): 382-438; and Breatnach, "Canon Law and Secular Law" (n. 18 above).

88 Bieler, Patrician Texts, 49, 246.

89 It has been argued that this is an example of the Church's imposition of levitical practices on Gaelic poets: Ó Corráin, Breatnach, and Breen, "Laws of the Irish," 400, 403-4. But 
suggested Fiacc as a poet who filled the requirements, including personal purity and being above reproach, and Fiacc became the first bishop among the Leinstermen. ${ }^{90}$ This anecdote about Fiacc is repeated in various contexts throughout Gaelic literary cultural history, sometimes filling out details and adding new ones.

\section{Fiacc Finn Sléibte}

Fiacc's consecration as first bishop of Leinster by Patrick is noted by Tírechán, an earlier contemporary of Muirchú. ${ }^{91}$ Tírechán's Collectanea were, apparently, intended as the basis for a Life of Patrick and show that both he and Muirchú had gathered, and were repeating, established tradition about Fiacc in their anecdotes. The outlines of the tale from the Additamenta about Fiacc's consecration, along with numerous other narrative details, are repeated in the late ninth- or early tenth-century macaronic Tripartite Life of Patrick in which Fiacc's only son, Fiachrae, is also named. ${ }^{92}$ The ninth-century martyrology Félire Óengusso, composed by Óengus mac Óengobann, cites both Fiacc and his son Fiachrae in its entry at 12 October. $^{93}$

Fiacc continued to practice his profession as poet, according to tradition, after becoming a cleric much as Colmán mac Lénéni is portrayed as having done. The

it would seem that this was a normative ideal seldom achieved in reality: Johnston, Literacy and Identity (n. 23 above), 140-41.

90 Bieler, Patrician Texts, 176-77. It is clear in all depictions of this episode, regardless of context, where Fiacc is selected for advancement into the church, that moral and ethical purity are expected of him as a member of the poetic class. Moral and ethical purity for newly conferred poets is stipulated in the law tract Uraicecht na Riar: Breatnach, Uraicecht na Ríar (n. 15 above), 104-5 (§6). Bede’s description of Cædmon implies the presence of similar, if not the same, personal characteristics.

91 Bieler, Patrician Texts, 128-29, 162-63. Tírechán may have written as much as a decade earlier than Muirchú.

92 Kathleen Mulchrone, ed., Bethu Phátraic: The Tripartite Life of Patrick (Dublin and London, 1939), 114-17, at 115. For questions about the dating of this text, see "The Dating of the Tripartite Life of St Patrick," in Saint Patrick, ed. David N. Dumville et al. (Woodbridge, 1993), 255-58.

93 Stokes, Félire Óengusso (n. 35 above), 216, 222-23. The scholia from various manuscripts confirm that Fiacc Finn Sléibte and his son Fiachrae are intended. The dating of Félire Óengusso has always been accepted as being Old Gaelic with recent opinions centering ca. 830: Riain, "The Tallaght Martyrologies, Redated" (n. 35 above), 21-38. However, David Dumville, while conceding the text's Old Gaelic status, has argued that the dating criteria are to be questioned and its composition may be later in the ninth century: David N. Dumville, "Félire Óengusso: Problems of Dating a Monument of Old Irish," Éigse 33 (2002): 19-48. Nevertheless, Liam Breatnach has supported the earlier dating (797x808) established by Rudolf Thurneysen as still reliable: Liam Breatnach, "Poets and Poetry," in Progress in Medieval Irish Studies, ed. Kim McCone and Katharine Simms (Maynooth, 1996), 74-75 (§4.4). More recently Pádraig Ó Riain has reasserted the arguments for dates from 829x833 for the Tallaght martyrologies: Feastdays of the Saints: A History of Irish Martyrologies (Brussels, 2006), 97-98, 118. 
Old Gaelic poem Fiacc's Hymn, a vernacular verse Life of St. Patrick found in the Liber Hymnorum, is attributed to him. ${ }^{94}$ Needless to say, the fifth-century poet and bishop could not have composed the Hymn, and its attribution to Fiacc must be seen as an example of using his auctoritas to lend prestige to the poem. One of the hymn's interesting features is the mention of ancestral figures Éber and Éremón, who form part of the national origin legend which is elaborated fully in later centuries in Lebor Gabála Érenn ("Book of the Taking of Ireland"). ${ }^{95}$ The hymn states that a sídflaith núae ("new prince of peace") was prophesied to come to the people of Ireland and that Tara would lie vacant. ${ }^{96}$ It also states that King Lóegaire's druids foresaw Patrick's arrival in Ireland and, hence, the coming of the faith. ${ }^{97}$ These topics just mentioned highlight the fact that the Gaels saw no incongruity in attributing to a venerated bishop, reputed to have been a professional poet, verses that portray legends of their pagan ancestors anticipating the arrival of the new Christian dispensation.

The prose preface to Fiacc's Hymn in the Liber Hymnorum repeats the aetiological legend first recorded in Muirchú's Life of St Patrick and expanded in the Additamenta, but this later prose preface fills out narrative details and provides motivation for some of the events. For example, once Fiacc accepted from Patrick his role in the Church, "tanic rath mór fair iarsein co roleg in n-ord n-eclastacda uile i n-oen aidche" ("thereupon a great grace came upon him, and he read all of the ecclesiastical rule in one night"), although the text acknowledges another version that claimed it took fifteen days. ${ }^{98}$ But Fiacc's suitability for the Church through divine grace is clear.

94 The Liber Hymnorum is preserved in two manuscripts, which both date to around 1100: Whitley Stokes and John Strachan, eds., Thesaurus Palaeohibernicus: A Collection of Old-Irish Glosses, Scholia, Prose, and Verse, 2 vols. (Cambridge, 1903; repr. Dublin, 1975), 2:xxxvxxxviii (manuscript), 2:307-21 (hymn). In the same manuscript an invocation to St. Patrick is attributed to either Niníne éces ("the poet") or to Fiacc of Sléibte: idem, Thesaurus, 2:322; Gerard Murphy, Early Irish Metrics (Dublin, 1961), 4.

95 Stokes and Strachan, Thesaurus, 2:316 (Éber and Éremón); R. A. Stewart Macalister, ed. and trans., Lebor Gabála Érenn: The Book of the Taking of Ireland, 5 vols. (London and Dublin, 1938-56).

96 Stokes and Strachan, Thesaurus, 2:314. Isidore of Seville noted how the sibyls were able to foretell relevant information about God and Christ: "Quarum omnium carmina efferuntur, in quibus de Deo et de Christo et gentibus multa scripsisse manifestissime conprobantur." José Oroz Reta and Manuel A. Marcos Casquero, eds. and trans., San Isidoro de Sevilla: Etimologías, 2 vols., 2nd ed. (Madrid, 1993), 1:710-13 (viii 8.7). Such prophecies are common in the Gaelic tradition and help explain why the Gaels are so frequently concerned with the naturale bonum of their ancestors. See, for example, Colin Ireland, "Some Irish Characteristics of the Whitby Life of Gregory the Great," in Early Medieval Ireland and Europe (n. 14 above), 139-78, at 153-59 ("Baptizing [virtuous] pagans").

97 Stokes and Strachan, Thesaurus, 2:314.

98 Ibid., 2:308. 
The preface to Fiacc's Hymn also provides information, confirmed by the genealogical tracts, to show that Fiacc was a member of the Uí Bairrche, an important Leinster family whose revered ancestor was Cathaír Már. ${ }^{99}$ Establishing the ancestry of any esteemed figure is an important function in Gaelic society. ${ }^{100}$

Our various accounts of Fiacc provide further contrasts with Cædmon. While Bede said that "he did not learn the art of poetry from men nor through a man," Fiacc is described as Dubthach's deiscipul ("disciple, pupil") in the Additamenta and as Dubthach's daltae ("pupil, fosterling") in the prose preface to Fiacc's Hymn. ${ }^{101}$ These terms emphasize Fiacc's participation in an organization that had formalized training or an apprenticeship. ${ }^{102}$ Cædmon could also "never compose any foolish or trivial poem but only those which were concerned with devotion." The Tripartite Life explains that when Patrick first visited Dubthach in Leinster to seek a candidate for bishop in the region, Fiacc was "hi tír Connacht co mbairtni donaib rígaib" ("in Connacht with bairdne for the kings"). ${ }^{103}$ Bairdne ("bardic craft," "eulogy") means that Fiacc was away on circuit in Connacht selling encomia to the local nobility. ${ }^{104}$ For the adoliscens poeta Fiacc to be on circuit with bairdne implies that he had not yet achieved the higher levels of the poetic arts (filidecht, the art of the fili). ${ }^{105}$ Nevertheless, his participation in the

99 For the genealogy as found in the prose preface to Fiacc's Hymn, see Stokes and Strachan, Thesaurus, 2:307; see further M. A. O'Brien, ed., Corpus genealogiarum Hiberniae (Dublin, 1962), 46 (121a39), 50 (121bc44); and Pádraig Ó Riain, ed., Corpus genealogiarum sanctorum hiberniae (Dublin, 1985), 41 (245), 46 (286), 48 (293), 99 (662.169), 121 (672.23), 128 (691). For references to the Uí Bairrche and Cathaír Már, see Francis John Byrne, Irish Kings and High-Kings, 2nd ed. (Dublin, 2001), 136-42.

100 Both Fiacc and Dubthach appear in the genealogies of the Gaels which contrasts with the case of the low-status Cædmon, who may not even have been Anglo-Saxon. The floruit and background of Cynewulf have not been ascertained: Thornbury, Becoming a Poet (n. 7 above), 120. We know little of Bede's personal background beyond what he tells us himself: $H E$ 5.24; Colgrave and Mynors, HE, xix-xxiii (discussion), 566-67 (Bede's account). We know more about the high-status Aldhelm and King Alfred: Michael Lapidge, "The Career of Aldhelm," Anglo-Saxon England 36 (2007): 15-69, at 17-22; Keynes and Lapidge, Alfred the Great (n. 29 above), 13-17 ("The Period of Alfred's Youth").

101 For the Additamenta, see Bieler, Patrician Texts, 176-77. For the preface to the Hymn, see Stokes and Strachan, Thesaurus, 2:307.

102 The eighth-century law tract Uraicecht na Ríar (n. 15 above) provides the most thorough surviving description of how this was organized.

103 Mulchrone, Bethu Phátraic, 115, lines 2224-25. The much earlier Additamenta (ca. 700) also acknowledge Fiacc's poetic circuit in Connacht at the time that Patrick requested a bishop from among Dubthach's students: Bieler, Patrician Texts, 176-77, viii 13.3.

104 Praise of a patron seems to have been a function of Gaelic poets of most ranks and levels of training. See Liam Breatnach, "Satire, Praise and the Early Irish Poet," Ériu 56 (2006): 63-84; and Tomás Ó Cathasaigh, "Early Irish bairdne "eulogy, panegyric," Studia Celtica Fennica 9 (2012): 54-61.

105 Kelly, Guide to Irish Law (n. 10 above), 46-47; for distinctions between fili and bard, see Breatnach, Uraicecht na Ríar (n. 15 above), 87-88, 99-100. 
poetic orders and his good character made him a worthy candidate for the higher ranks of the early Church.

\section{Dubthach maccu Lugair}

In Muirchú's account, Dubthach maccu Lugair, the professional poet present at the royal court, is described as a poeta optimus, translated by Bieler as "excellent poet," but better treated as an ollam filed ("chief poet"). ${ }^{106}$ When Patrick and his companions arrived, Dubthach was "the first on that day to believe in God, and it was counted to him for righteousness." ${ }^{107}$ In other words, Dubthach is immediately drawn into the ambit of the Church, and the implicit reference to the patriarch Abraham suggests his role in helping to lead the Gaels into a new dispensation.

Dubthach figures centrally, along with Patrick, in an etiological legend that purports to explain the process of syncretism between native legal traditions and the teachings of the Christian Church. ${ }^{108}$ The legend, which survives in variant versions, is given expression in what has been called the "pseudo-historical prologue" to the Senchas Már ("The Great Tradition"), a major law tract compilation. ${ }^{109}$ The "pseudo-historical prologue" survives in three varying versions preserved in three separate manuscripts. ${ }^{110}$ The most recent editors agree that the language of the prologues is consistent with the eighth century. ${ }^{111}$ The syncretism is presented in the form of a leading legal case. ${ }^{112}$ King Lóegaire and his court advisors were concerned that the Christian doctrine of forgiveness would disrupt the existing societal structures and controls. In order to test the doctrine, it was decided that a member of Lóegaire's court, Nuadu Derg, would slay a

106 Kelly, Guide to Irish Law, 48; Breatnach, Uraicecht na Ríar, 102-5 (§§2-6).

107 "Crediditque primus in illa die Deo et repputatum est ei ad iustitiam," Bieler, Patrician Texts, 92-93, I 19 (18).4.

108 For a discussion of this episode of blending old and new traditions and the responsibilities of a spokesperson, see Joseph Falaky Nagy, Conversing with Angels and Ancients: Literary Myths of Medieval Ireland (Dublin, 1997), 201-8. For public performance of the legal process including, in this case, a poet's reliance on inspiration, see Stacey, Dark Speech (n. 87 above), 84-85, 90-91, 141-42, 163-66.

109 First discussed by D. A. Binchy, "The Pseudo-Historical Prologue to the Senchas Már," Studia Celtica 10-11 (1975-76): 15-28. For more on the Senchas Már, see Kelly, Guide to Irish Law, 48, 242-46, 248.

110 For discussions and editions of significant parts of the "prologue," see Kim McCone, "Dubthach maccu Lugair and a Matter of Life and Death in the Pseudo-Historical Prologue to the Senchas Már," Peritia 5 (1986): 1-35; John Carey, “The Two Laws in Dubthach's Judgment," Cambridge Medieval Celtic Studies 19 (1990): 1-18; and idem, "An Edition of the Pseudo-Historical Prologue to the Senchas Már," Ériu 45 (1994): 1-32.

111 McCone, "Dubthach maccu Lugair," 19; Carey, "Two Laws," 3-4; idem, "Edition of Pseudo-Historical Prologue," 9.

112 Examples of Early Gaelic stories that serve as leading legal cases or that illustrate legal formulae have been gathered by Myles Dillon, "Stories from the Law-Tracts," Ériu 11 (1931-32): 42-65. 
member of Patrick's entourage, Odrán, Patrick's charioteer, in order to see how the saint would respond. It was left to Dubthach to pronounce judgment on the murderer. Being a trained fili ("poet"), Dubthach's judgment was presented in the form of an obscure, unrhymed, alliterating poem. ${ }^{113}$

Dubthach was worried about the responsibility of pronouncing on the murder, understanding fully the quandary he was in. Patrick encouraged Dubthach that whatever he said would come from God. ${ }^{114}$ So Dubthach submitted himself to God and Patrick in order to produce his inspired poem and make the correct judgment. The final judgment was that the murderer, Nuadu Derg, must lose his life for having murdered but, since he was not baptized and had not yet received the faith, his murder was not held against his soul, his sin could be expiated, and he could be granted a place in heaven. ${ }^{115}$ We then have the allegorical explanation of how a group of nine named, high-status men were brought together to reconcile the teachings of the Church with the laws and customs of the Gaels. This ostensible committee consisted of three kings, three bishops, and three learned men, two of the latter three being Dubthach himself and another poet named Fergus fili. ${ }^{116}$

In addition to the preface to the Senchas Már, the story of Dubthach's participation in the syncretism of Church and secular law is outlined in the eighthcentury law tract Córus Bésgnai ("The Regulation of Proper Behavior"). ${ }^{117}$ In both law tracts, Dubthach is among the people who, along with Patrick, examined native Gaelic law and harmonized those parts of it that did not contradict Christian conscience with Holy Scripture and the Church's teachings.

We see the story of Patrick's arrival at the pagan court of Lóegaire mac Néill again in the later prose narrative Comthóth Lóegairi co cretim ocus a aided ("Lóegaire's conversion to the faith and his violent death") preserved in the early twelfth-century manuscript Lebor na hUidre. ${ }^{118}$ The text is in the hand of an

113 The poem is edited from the only surviving manuscript, BL, Harley 432, by McCone, "Dubthach maccu Lugair," 5-10 (English), 29-35 (Gaelic and textual notes). See another translation: Carey, "Two Laws," 13-15.

114 McCone, “Dubthach maccu Lugair," 6 (§3); Carey, "Edition of Pseudo-Historical Prologue," $18(\S 6)$.

115 McCone, "Dubthach maccu Lugair," 6-8 (§§i-xx [poem], §5 [summary]). Irish canon law placed a greater emphasis on the death penalty than did the secular law: Kelly, Guide to Irish Law, 214-24 (punishments); Colin Ireland, ed., Old Irish Wisdom Attributed to Aldfrith of Northumbria: An Edition of Bríathra Flainn Fhína maic Ossu, Medieval and Renaissance Texts and Studies 205 (Tempe, AZ, 1999), 149-50 (§6.70).

116 McCone, "Dubthach maccu Lugair," 8-10 (§§6-8); Carey, "Edition of Pseudo-Historical Prologue," 18-19 (§§7-11).

117 Ó Corráin, Breatnach, and Breen, "Laws of the Irish" (n. 87 above), 385-86, 399; McCone, "Dubthach maccu Lugair," 10, 20-26; Carey, "Two Laws," 2-3, 8.

118 R. I. Best and Osborn Bergin, eds., Lebor na Huidre: Book of the Dun Cow (Dublin, 1929), 293-95, $117^{\mathrm{b}} 20-118^{\mathrm{b}} 44$. See an early translation by Charles Plummer, "The Conversion of Loegaire, and His Death," Revue celtique 6 (1883-85): 162-72. 
interpolator, referred to as $\mathrm{H}$, who was working long after the manuscript had been compiled. Most of the tale is based on the "pseudo-historical prologue" of the Senchas Már and relates the traditions about Dubthach cooperating with Patrick to blend Gaelic tradition and Church teachings as part of the conversion of the Gaels. But the tale then shifts to Lóegaire's battles with the Leinstermen and the collection of the bórama tax. When Lóegaire is captured by his enemies, pledges are given, based on the elements of nature, that seem to reflect pre-Christian practice. The tale relates, "the just sanction of the elements of God, it is this which killed Loegaire."119 Lóegaire was buried in full armor on a ridge of Tara facing southward towards his enemies. This burial reflects presumed pre-Christian practice and is drawn from Tírechán's account of Lóegaire in which, unlike Muirchú's Vita Patricii, Lóegaire does not accept the faith and is not converted. ${ }^{120}$ Muirchú's benign treatment of Lóegaire is different from many of the surviving traditions where Lóegaire can represent the reluctance to renounce paganism. ${ }^{121}$ Comthóth Lóegairi draws on some clearly identifiable (contradictory) sources and serves as a reminder that the path to conversion among the Gaels was not free of obstacles.

Dubthach maccu Lugair also plays a role in the ninth-century Bethu Brigte ("Life of St Brigit"). ${ }^{122}$ In this saint's Life, Dubthach comes as a suitor to Brigit's father seeking Brigit in marriage. Brigit, however, refused the offer and suggested instead another young maiden. She blessed Dubthach's mouth so that his marriage proposal to the other maiden would be successful and all transpired as Brigit had predicted. ${ }^{123}$ Both Brigit and Dubthach descended from Leinster lineages, but Dubthach came to represent Patrick's paruchia based in Ulster at Armagh, and Brigit represents Kildare in Leinster. Armagh eventually dominated. ${ }^{124}$ This episode in the ninth-century Bethu Brigte appears to be an allegorical expression of Kildare's desire to maintain independence.

119 Plummer, "Conversion of Loegaire," 168.

120 Tírechán and Muirchú were contemporaries with Tírechán writing perhaps a decade before Muirchú. Their different versions of the success of the Patrician mission to Lóegaire's court show the evolving nature of ecclesiastical politics as reflected by these two hagiographers. For Tírechán's account, see Bieler, Patrician Texts (n. 2 above), 132-33, 12 (1-2).

121 For discussions, see Gearóid Mac Eoin, "The Mysterious Death of Loegaire macc Néill," Studia Hibernica 8 (1968): 21-48; and Joseph Nagy, "Excavating Lóegaire mac Néill," in Saltair Saíochta, Sanasaíochta agus Seanchais, ed. Dónall Ó Baoill, Donncha Ó hAodha, and Nollaig Ó Muraíle (Dublin, 2013), 181-89. The case of Lóegaire can be compared to the continental story of King Radbod's refusal to accept baptism. See Rob Meens, "With One Foot in the Font: The Failed Baptism of the Frisian King Radbod and the 8th-Century Discussion about the Fate of Unbaptized Forefathers," in Early Medieval Ireland and Europe (n. 14 above), 577-96.

122 Donncha Ó hAodha, ed., Bethu Brigte (Dublin, 1978).

123 Ó hAodha, Bethu Brigte, 4-5 (§14) (Gaelic), 23 (English), 45nn.

124 The seventh-century Liber Angeli is a document that purports to explain Armagh's prerogatives in ecclesiastical dominance: Bieler, Patrician Texts, 184-91. See also Kathleen Hughes, The Church in Early Irish Society (Ithaca, 1966), 275-81. 
Like Fiacc, Dubthach is portrayed as a professional poet throughout the tradition, and his Leinster lineage is the reason for the association. Three poems are attributed to him in the Lebar na Núachongbála ("The Book of Leinster"), all three of which are about Leinster heroes and dynasties and their eponymous ancestors. ${ }^{125}$ The attribution of these poems to Dubthach is another example of using his name to add auctoritas. In the same way Dubthach, or a poet of his lineage, also has poetic fragments attributed to him in the Leinster genealogies. ${ }^{126}$ James Carney cited a seldom-noted tradition that Patrick was buried in Leinster along with Dubthach among the Cenél Lugair. ${ }^{127}$

In a poem on Gaelic authors and laws, composed by Gilla in Choimded Úa Cormaic, sometime between 1050 and 1150, Dubthach and the others of the nine experts from the allegory who worked on the syncretism that resulted in the Senchas Már are all cited. ${ }^{128}$ This legal poem was written in the era when some of the poems on Leinster lineages and heroes attributed to Dubthach mentioned above may have been composed. It shows that, by the end of the AngloSaxon era, these Gaelic traditions reflected in the eighth-century "pseudo-historical prologue" continued to impact Gaelic intellectual life, and these cultured experts of a much earlier period survived into later centuries as icons of the tradition.

\section{Conclusions}

We have examined two accounts by clerics writing in Latin that named three vernacular poets who have impacted subsequent cultural history. The three poets qualify as fir fíréoin ("righteous men"). John Carey has highlighted the importance of this Gaelic term in the pre-conversion context of men like Dubthach and Fiacc; but it could be extended to the process of converting

125 R. I. Best, Osborn Bergin, and M. A. O'Brien, eds., The Book of Leinster formerly Lebar na Núachongbála (Dublin, 1954), 1:215-22. The poems have been translated by Eugene O'Curry, Lectures on the Manuscript Materials of Ancient Irish History (Dublin, 1861; repr. 1995), 482-94.

126 O'Brien, Corpus genealogiarum (n. 87 above), 70-72. See also Ó Riain, Corpus genealogiarum sanctorum (n. 99 above), 50 (305), 78 (653), 117 (670.72), 169 (722.2).

127 James Carney, The Problem of St. Patrick (Dublin, 1961), 121 and nn. The presumed locations would be near Gorey, Co. Wexford: Hogan, Onomasticon (n. 2 above), 221 (Cenél Lugair), 345 (Dind fhlatha ceneoil lugair).

128 Peter Smith, "Aimirgein Glúngel Tuir Tend: A Middle-Irish Poem on the Authors and Laws of Ireland," Peritia 8 (1994): 129-30 (Gaelic), 136-37 (English) (\$§33, 37-40). For another Middle Gaelic text that mentions Dubthach maccu Lugair in the context of poets, judges, and the Senchas Már, see Roisin McLaughlin, "A Second Source for the Text on Judges and Poets in the Pseudo-Historical Prologue to the Senchas Már," Celtica 27 (2013): 18-37, at 32-33 (§2). 
others, as Cædmon helped to do. ${ }^{129}$ Cædmon was righteous in the manner of his death and his own foreknowledge of it. Dubthach was righteous in honoring Patrick and accepting the faith before others at the pagan court. ${ }^{130}$ Fiacc's good character and manner of living made him a natural candidate for bishop.

All three poets were "inspired" individuals. Both Cædmon and Dubthach produced inspired poems. Cædmon composed "by the grace of God" and entered monastic life. Dubthach's judgment poem, inspired through God and Patrick, motivated the conversion of Lóegaire's hesitant court and helped institute the legendary movement to syncretize Church teachings and Gaelic tradition. Once Fiacc accepted his role in the Church, he was inspired by divine grace to learn the ecclesiastical rule in short order. The qualities of righteousness and inspiration in these early poets are shared by both traditions.

There are significant distinctions between the two accounts. Bede was writing within a few generations of the conversion of Anglo-Saxon society. Muirchú, although describing pivotal events of the conversion of the Gaels, was writing at a remove of at least two centuries from those events. The differences in the attitudes of the two clerics may reflect the relative distance from each society's conversion with Bede necessarily being the more circumspect. Bede's cautious attitude is reflected in his insistence that Cædmon was incapable of composing on "trivial" topics. Nevertheless, scholars have long noted the encomiastic diction of his Hymn. ${ }^{131}$ Muirchú, and other Gaelic hagiographers, accepted the secular duties and functions of vernacular poets, including composing encomia, as seen with Fiacc bringing bairdne to the nobility.

Cædmon is unique for his low social status among both Gaelic and Anglo-Saxon named vernacular poets, including those in Widsith and Deor, and an unnamed poet in Beowulf. ${ }^{132}$ Given Bede's account of his own obscure social background (HE 5.24), Cædmon's low status — exacerbated by uncertain ethnic origins may have resonated with Bede's personal experience. ${ }^{133}$ Bede described

129 For Dubthach and Fiacc, see Carey, "Two Laws," 8-10. For Cædmon, see Peter Hunter Blair, "Whitby as a Centre of Learning in the Seventh Century," in Learning and Literature in Anglo-Saxon England: Studies Presented to Peter Clemoes on the Occasion of His Sixty-fifth Birthday, ed. Michael Lapidge and Helmut Gneuss (Cambridge, 1985), 3-32, at 24-25.

130 It could be argued that Dubthach's actions in accepting the faith ahead of his countrymen and honoring Patrick when others doubted him makes Dubthach an example of the naturale bonum; see n. 96 above.

131 O'Donnell, Cadmon's Hymn (n. 6 above), 67-76.

132 Fulk, Bjork, and Niles, Klaeber's Beowulf (n. 38 above), cxxi-cxxii, 31 lines 867b874a, 165-66nn.; Thornbury, Becoming a Poet (n. 7 above), 17-19.

133 Colgrave and Mynors, HE (n. 3 above), 566-67; Charles Plummer, Venerabilis Baedae Opera Historica (Oxford, 1896), 1:ix-xi; Patrick Wormald, "Bede, 'Beowulf' and the Conversion of the Anglo-Saxon Aristocracy," in Bede and Anglo-Saxon England: Papers in Honour of the 1300th Anniversary of the Birth of Bede, ed. R. T. Farrell (Oxford, 1978), 32-95, at 61-63; 
Cædmon seemingly by way of contrast to a traditional Anglo-Saxon poet; Cædmon was a low-status layman, mature in years, who never learned poetry from human teachers and who avoided public performance. Bede's negative depiction of Cædmon's poetic background provides, ironically, the most complete account of a functioning poet preserved in any records, Latin or vernacular, from Anglo-Saxon society. ${ }^{134}$ A challenge for scholars of Old English literature is to determine where on the spectrum from antithesis to epitome Bede's account of Cædmon represents the practice of Anglo-Saxon poets.

Just as Cædmon changed his teachers into his audience, he was himself converted and elevated, in Bede's eyes, from the lay to the religious life. This lifestyle elevation may have suited Bede's purposes given the recent memories of the Anglo-Saxon conversion. Muirchú, by contrast, accepts the prestige that highstatus poets bring to the Church. Bede assures us that Cædmon had no training in poetry and did not learn any of his skills from other men. Dubthach and Fiacc, conversely, participated in the formal training and apprenticeship systems of the Gaelic professional poets. Bede wanted his readers to see Cædmon's poetic talent as a divinely inspired gift, but formally trained Gaelic poets also relied on, or were purported to rely on, poetic inspiration, whether the source was human or divine.

The most striking contrast between the two literary cultures is the vibrant intertextuality and self-referential tendencies of the Gaelic tradition that cannot be matched by the Anglo-Saxon. Cædmon exists only in Bede's Historia Ecclesiastica. It can be argued that Bede attempted to create an air of sanctity around Cædmon in order to elevate his status. ${ }^{135}$ Traces of Dubthach and Fiacc, conversely, are frequent in Gaelic tradition where they are found in law tracts, in hagiography, in martyrologies, in genealogies, in prose narratives, and in other poems. Their reputations apparently preceded Muirchú's writing, as suggested by their inclusion in the nearly contemporary, but more detailed,

repr. in The Times of Bede, ed. Stephen Baxter (Malden, MA and Oxford, 2006), 30-105, at 62-64; Chris Wickham, Framing the Early Middle Ages (Oxford, 2005), 324.

134 For up-to-date discussions that attempt to place Cædmon, as related by Bede, in the larger context of Anglo-Saxon poetic culture, see O'Donnell, Coedmon's Hymn, 1-28; and Thornbury, Becoming a Poet, 5-8. I wish to thank Professor Mary Clayton and the anonymous readers of this essay for thought-provoking comments along these lines. I alone am responsible for the final form of the arguments.

135 Wieland, "Cædmon, the Clean Animal" (n. 59 above), 198; Hunter Blair, "Whitby as a Centre of Learning," 24-25; Allen J. Frantzen, Desire for Origins: New Language, Old English and Teaching the Tradition (New Brunswick, NJ and London, 1990), 143-44; Daniel Paul O'Donnell, "Bede's Strategy in Paraphrasing Coedmon's Hymn," Journal of English and Germanic Philology 103 (2004): 417-32, at 423-24, 429-30; O'Donnell, Cadmon's Hymn, 4-5, 78; Bruce Holsinger, “The Parable of Cædmon's Hymn: Liturgical Invention and Literary Tradition," Journal of English and Germanic Philology 106 (2007): 149-75, at 150, 157, 175; Cronan, "Cædmon's Audience" (n. 5 above), 360-63. 
Additamenta (ca. 700) and Fiacc's appearance in the earlier work by Tírechán (ca. 680). If Muirchú had not mentioned Dubthach and Fiacc in the Vita Sancti Patri$c i i$, we would still know about them, be able to recreate something of their personal histories, and recognize their contributions to Gaelic cultural history.

Bede had devoted an entire chapter to Cædmon synopsizing, in essence, his career and literary influence. Muirchú had mentioned Dubthach and Fiacc only briefly, highlighting specific points about each one: Dubthach was the first at court to believe on the day, and Fiacc would become the founding bishop of Sléibte. Yet subsequent literary history treats these three poets very differently. Cædmon is not recorded outside of Bede's account until after the Anglo-Saxon period. The careers of Dubthach and Fiacc, alternatively, must be filled out from references in a wide array of sources and various genres for the same timeframe. It would appear that professional status, formalized training, and legal recognition of rank may have contributed to greater acknowledgement for Gaelic vernacular poets than that achieved by their Anglo-Saxon counterparts.

The vernacular literatures of early medieval Europe evolved, in part, as a result of the conversion to Christianity. The study of these literatures must be conducted against the background of the Church's Latinate teachings, which helped disperse widely the learning of Mediterranean cultures to western and northern Europe. Both Early Gaelic and Old English vernacular literatures developed as a result of these contacts and transformations and have much to reveal about the processes.

Arcadia University, Emeritus

University College Dublin, Adjunct

Keywords: Bede, Muirchú, vernacular poets, Cædmon, Dubthach, Fiacc 